\title{
USER EXPECTATIONS ON SMART TV; AN EMPIRIC STUDY ON USER EMOTIONS TOWARDS SMART TV
}

\author{
Deniz Yeșim TALUĞ \\ Hacettepe Üniversitesi, Türkiye \\ deniz.talug@gmail.com \\ https://orcid.org/0000-0003-1897-3583

\begin{tabular}{|l|l|}
\hline \multirow{3}{*}{ Atıf } & $\begin{array}{l}\text { Taluğ, D, Y. (2021). AKILLI TV'DE KULLANICI BEKLENTILERİ; AKILLI TV’YE } \\
\text { YÖNELIK KULLANICILARIN DUYGUSAL BEKLENTILERİ ÜZERINE AMPIRIK BIR } \\
\text { ÇALIŞMA. The Turkish Online Journal of Design Art and Communication, 11 (1), 424-442. }\end{array}$ \\
\hline
\end{tabular}

\begin{abstract}
As a result of the introduction of new technologies in consumer electronics, analog TV shifted from a mere viewing experience to a personalized digital TV experience where users are encouraged to interact. The application of these new technologies not only create changes in physical appearance and adding more functionalities to TVs but it also shifts user expectations, which are mainly emotionally driven. The initial attempt of this study is to determine which emotions are involved in smart TV preference and why those particular emotions are aroused. In other words, this study aims to discover the link among contents, activities and user interaction as well as the relationship between triggered emotions and user expectations. By doing so, it analyses user emotions and expectations towards a dream TV. The primary data is collected towards semi-structured in-depth interviews. The results show that Smartness, High quality, Personalization, Functionality and Appearance are the key features that meet the expectations towards TV experience. User-friendliness, compatibleness, enjoyableness, awareness, novel-interactions, self-defense smart software and voice remote are the consequent expectations. All these expectations arise from different underlying emotional tendencies. With its initial attempt to propose guidelines for designers, this study suggests that for designing a smart TV that meets user expectations, its design should enable smart interaction that simplifies managing task (Smartness), high quality of picture and sound to enable innovative continuous experience (High quality), supporting not missing any content of interest and filter unwanted ones (Personalization), utilize all kinds of usage comfortably (Functionality), and should have an aesthetic look, even seamless design that fits any possible environment (Appearance).
\end{abstract}

Keywords: Smart TV, Interaction, User Expectations, Emotional Design, Product Experience, Technology.

\section{AKILLI TV'DE KULLANICI BEKLENTILERİ; AKILLI TV'YE YÖNELIK KULLANICILARIN DUYGUSAL BEKLENTILERI ÜZERINE AMPİRIK BİR ÇALIŞMA}

ÖZ

Tüketici elektroniğinde, yeni teknolojilerin kullanılmasının bir sonucu olarak, analog TV, salt bir izleme deneyiminden, kullanıcıların etkileşime girmeye teşvik edildiği kişiselleştirilmiş bir dijital TV deneyimine doğru evrilmektedir. TV'de yeni teknolojilerin kullanılması, yalnızca fiziksel görünümde değişiklikler yaratmak ve daha fazla işlev eklemekle kalmaz, aynı zamanda (esas olarak duygular tarafından yönlendirilen) kullanıcı beklentilerini de değiştirir. Bu çalışmanın temel sorunsalı, akıllı TV tercihinde hangi duygusal beklentilerin yer aldığını belirlemek ve bu belirli duyguların neden uyandığını görmektir. Diğer

Submit Date: 12.01.2021, Acceptance Date: 01.02.2021, DOI NO: 10.7456/11102100/007

Research Article - This article was checked by iThenticate

Copyright (C) The Turkish Online Journal of Design, Art and Communication 
bir deyişle, bu çalışmanın amacı, içerik ve faaliyetler ile kullanıcı etkileşimi arasındaki ilişkinin yanı sıra tetiklenen duygular ve kullanıcı beklentileri arasında olan ilişkiyi anlamaktır. Bunu yaparak, rüya (hayal edilen) TV'ye yönelik kullanıcı duygularını ve beklentilerini analiz etmektedir. Veriler, yarı yapılandırılmış derinlemesine görüşmeler ile toplanmıştır. Sonuçlar, Akıllılık, Yüksek Kalite, Kişiselleştirme, İşlevsellik ve Görünümünün TV deneyimine yönelik beklentileri karşılayan temel özellikler olduğunu göstermektedir. Kullanıcı dostu olma, uyumluluk, keyif alma, farkındalık, yeni etkileşimlere olanak sağlama, kendini korumaya yönelik akıllı yazılım ve sesli uzaktan kumanda ise beklentileri karşılayan diğer önemli nitelikler olarak ortaya çıkmıştır. Tüm bu beklentiler, altta yatan farklı duygusal eğilimlerden kaynaklanmaktadır. Tasarımcılar için ilkeler önerme girişimiyle tamamlanan bu çalışma, kullanıcıların duygusal temellere dayanan beklentilerini karşılayan bir akıllı TV tasarlamak için tasarımının beş temel unsuru içermesi gerektiğini ortaya koymaktadır. Bu unsurlar; görevleri başarmayı basitleştiren akıllı etkileşimin sağlanması (Akıllılık), yeni ve sürekli deneyim canlı tutulması için yüksek kaliteli görüntü ve ses (Yüksek Kalite), beğenilen herhangi bir içeriğin ulaşılabilir olmaması ve istenmeyenlerin filtrelenmesi (Kişiselleştirme), farklı kullanım biçimlerine olanak sağlanması (Fonksiyonellik), ve estetik bir görüm ile olası her ortama uyan kusursuz bir tasarıma sahip olma (Görünüm), olarak belirlenmiştir.

Anahtar Kelimeler: Akıllı TV, Etkileşim, Kullanıcı Beklentileri, Duygusal Tasarım, Ürün Deneyimi, Teknoloji.

\section{INTRODUCTION}

Television (TV) is a media tool generally available in many houses establishing an essential role in family's social activities along other points of interaction linked to it. In other words, TV is a center of interest and social interaction in home environment. Although TV seems to have a specific function and it seems to serve for a certain purpose, in today's shifting world habits and styles, reasons of watching TV differ immensely between individuals with different personal interests, age range, gender, educational backgrounds, and socio-economic status. While TV's functions, importance and popularity increases drastically day by day, TV is becoming a quite popular research subject in many different fields, both for technological aspects and for its social and/or psychological effects. To this end, researchers and academics began to discuss and explore on the meaning and function of TV in society as a part of mass media communication. For example, researchers of both informatics and some other engineering disciplines or social studies and multidisciplinary researchers work on how to integrate new technological discoveries to TVs and which practicalities and opportunities these technological developments will provide (Saxbe et. al., 2011: 180-186; Tsekleves et. al., 2011: 152-156; Bellman et. al., 2010: 67-80; López-Nores et. al., 2011: 12691-12698; Montpetit et. al, 2011: 519-531; Chorianopoulos \& Lekakos, 2008: 113-119; JumiskoPyykkö et. al, 2008: 183-191).

As a recurring interdisciplinary theory "Activity Theory" explores both cognitive and social activities that arise around technological products and the modification of existing ones (Kaptelinin et al., 1999: 28-31; Kaptelinin, 2003: 832; Kaptelinin et al., 2006:73). Another theory that can be associated with this subject, "Domestication Theory" tends to determine how users adopt themselves to these technologies, and develop new patterns of practice for products based on these technologies, mostly that are unpredictable by designers during the process of creation. The theory also analyses the effect of these technologies on a micro level within households and how it affects our daily lives on a macro approach (Berker, 2005: 3-4, Richardson, 2009: 599-602).

The study of consumers affiliation with the new technologies integrated to everyday products emphasized the connection between the decision-making process and our emotions. As emotions seemed to be one of the most important aspects for the decision, determining them and being able to measure them became one of the most popular topics in modern literature. There is also an increasing number of papers intended for designers such as the works of Hassenzahl and Tractinsky, 2006: 93; Desmet and Hassenzahl, 2012: 22-25;

Submit Date: 12.01.2021, Acceptance Date: 01.02.2021, DOI NO: 10.7456/11102100/007

Research Article - This article was checked by iThenticate

Copyright (C) The Turkish Online Journal of Design, Art and Communication 
Hassenzahl, 2013: 2; Chen and Chu, 2012: 2012; Saraiva and Ayanoğlu, 2019: 65-66, Norman, 2004: 6396, Gobé, 2010: 71-99-283 on how to satisfy consumers emotional expectations.

This paper tends to determine analyze the emotions towards TV usage as a smart product in the light of technological improvements. It will show, by using the intersection points of existing literature and the results of the study; how people will use Smart TV technologies, when it will be possible for them to have access on their cars, homes or mobile phones, and determine the emotions in play while they are going to domesticate Smart TV. In short, this paper aims to shed light on what context, in which environment, with what kind of expectations and what sort of a TV experience people desire. Consequently, it can lead to a guideline that consists of some new perspectives for the designers and manufacturers.

The first section of this paper emphases on the activity and domestication theories, describing these theories and putting forward their basic assumptions will reveal the main arguments about user needs and expectations on new technologies. The second section of the paper includes description of TV both as traditional TV and as the concept of "smart TV". Also, the observations and studies on the presentation of this fairly new concept are mentioned. The analyses in this section mainly focus on various significant studies that discuss the changes in TV experiences and different expectations from such experiences. The third section, focuses on the relationship among user experiences and emotions next Desmet's tool for measuring emotional impact of a product is defined and presented. Then, an empirical research on how to measure and improve satisfaction in TV experience is introduced. Discussions and conclusion take part at last section of the paper.

\section{LITERATURE SURVEY}

\section{Activity Theory and Domestication Theory}

Activity Theory is a fundamental approach in psychology and other disciplines which aims to understand human behavior by analyzing the origin, the nature and procedures of their social activities, Therefore, the concept of activity is the most fundamental matter. In general, activity examines not only human mobility, but also the movement of the object, the process and interaction between "subject-object" is studied (Leontiev 1978, as cited in Kaptelinin and Nardi, 2006: 31). In design, the "Activity Theory" tends to determine how new technologies are being used within certain contexts. Within a certain context, new actions and activities associated to this new technology will emerge and meet consumers motivations/expectations and arouse emotions. The activities will be triggered by needs and desire which are emotions hidden behind the motivations (Kaptelinin et. al., 1999: 29). Therefore, the actions of a consumer points to his/her needs and desires. Every consumer has a personalized way of using a given product. Researchers need to examine how users might utilize the new technology beyond intended functions. A consumer can use the TV to play video games while others can use it to practice another language throughout a movie. To meet users' expectations for a product, one should explore users' actions and activities and their related contexts. For that reason, to further understand the use of TV and how it is adapted it in users lives, there is a need for exploring the context of activities in which users interact with $\mathrm{TV}$ and their emotional influences in more detail.

The Domestication Theory, as its name may implies, is about the process of acceptance or rejection of a new technology and / or a new product in our daily life and its permanence and use. If these technologies are integrated to user's daily life and environment, as a comfortable, functional, enjoyable, useful and trustworthy tools rather than being difficult, unresponsive and cold, domestication of them has been successful (Berker, 2005: 3). This theory concerns both technologies adaptation to user and the users who create environments where technologies are more common. From this point of view, it is seen that the technology is shaped by the users and thus unforeseen usage patterns that are not included in the design process are formed (Richardson, 2009: 600). Thus, working on user interactions with a prototype during the design process and involving users, would provide more satisfying results to meet user expectations.

Submit Date: 12.01.2021, Acceptance Date: 01.02.2021, DOI NO: 10.7456/11102100/007

Research Article - This article was checked by iThenticate

Copyright (C) The Turkish Online Journal of Design, Art and Communication 
By determining the role of technology and its adaptation in daily life, in the light of these theories, we can see that in the process of adoption of a new technology/product by the users the key factors are gender, culture, social and economic background and lifestyle. This will help to understand why expectations and emotions are different among users when they are adopting a new technology or product.

\section{New TV Experience}

The TV, dating back nearly hundred years, was improved and became widely available in the 1980s. Since then, they have assumed new forms and met with its users. The television, which first settled in the most beautiful corner of the living room, which is the main center of the house, then multiplied and entered the other rooms and became a part of the house. In this sense, the television was taken to the center while organizing the space, and then the social life that would develop in this space, in a sense, expectations, hopes, future and emotions began to be organized around TV and its presence. As Berker (2005: 29) says, our personal memories are structured around TV, especially media experiences such as symbolic cartoons and characters of our childhood.

Nowadays, with the dominance of Internet technology good old analog TV got into the province of Internet and renamed as Smart TV. What does the name Smart TV (this new name for TV) suggest? In smart TVs, Internet technologies are integrated into TV. This technology offers many new opportunities and functions to the user. In this context it may be illuminating to envision the experience of the rapid transformation the mobile phones into Smart phones, with all the added functionalities enabled by internet technologies. As Eliseo Veron and colleagues (1991) describes in detail the similar journey of phone in the house as it proliferates from the public space to the rooms of the house. Today, in the age of mobile phones, the phone has become completely personalized and perceived as a body part by many users, becoming the virtual address of the person, consequently land lines have become a secondary communication facility that is not used by many people. TV technology is also in the process of similar change and the first examples took their place on the stage. It is clear that lifestyles and family life are changing as people seek to adapt and cope with new technologies. Therefore, active research topics of the literature, whether for TV or other technological products, is how unknown and challenging technological ground can be adopted and domesticated to make it less intimidating, controllable and enjoyable for users.

With all its astonishing developments, TV has changed from being a viewing tool into an interactive smart product, which can be personalized. Interactive Television (iTV) offers dramatic innovations in recent years that transform the traditionally passive TV experience into an interactive experience. Thus, the new TVs provoke the consumers to purchase with their altered look, much different from the previous appearance and technological architecture. For example, Samsung in collaboration with University of California introduced a TV capable of producing a variety of scents (URL-1, University of California - San Diego, 2011). Also, 4D TVs are available, and hologram technologies integrated to televisions for changing the viewing perception and bringing new experiences. Another example is seats that are sold with TVs to let viewers experience related bodily sensations while watching the content. These TVs with new technological features are the pioneers of the future TVs. Therefore, the discourse on the potential of existing TV technologies and how they will meet with the users are active contemporary area of research and publication. Tsekleves, Cosmas, Aggoun, and Loo (2009: 1-19) state in their research that there is a trend towards an interactive TV experience that enables user to explore basic games and send basic sings or conversation to the broadcaster through the use of audio, video, graphics and text elements. In addition, there has been a tendency about providing a more enhanced TV experience by linking computer related features such as web browsing, video clips, e-mail, blogs etc. In short, these researchers are referring to the five development axes that Smart Television will develop in the next few years, in line with developments in digital platforms and wireless networks, namely; IPTV, Mobile TV, Personalized TV, Smart Space TV and 3D TV

Submit Date: 12.01.2021, Acceptance Date: 01.02.2021, DOI NO: 10.7456/11102100/007

Research Article - This article was checked by iThenticate

Copyright (C) The Turkish Online Journal of Design, Art and Communication 
(Tsekleves, Cosmas, Aggoun, and Loo 2009, 11-16). We can see that some of these pioneering TV's are already in production.

Studying on TV usage, experience and user expectations De Moor et al. (2014: 45-47) as a result of various studies involving experts and users, point main directions and trends about future TV experiences and TV technologies. These are; the growing communication among TV, PC and internet, evolution of 3D television to holographic TV and/or 4D TV, where additional sensory effects will be added to the TV set of the future, creating even more immersive TV experience, which evolves to multi-screen content consumption, becoming more and more mobile and rich, social viewing and video chat facilities while viewing, sharing media content over connected TV platforms, and finally, the necessity for revolutionary user interfaces and personalized content. As stated before, TV sets with some projected technologies have taken their place in the market.

In addition to the extensive literature on TV technologies, there is a wide literature on the watching habits and socialization with TV, of male, female and children. Until recently TVs were usually put in the living room, bedroom or the kitchen, right in front of the dining table. In a study conducted by Saxbe et al. (2011: 180-189) thirty families are interrogated. The study revealed the watching patterns of family members. The main objective of this research is to find out whether TV watching is a solo or social activity. Results indicate that television viewing patterns differ among family members. While parents perceive TV viewing as a social activity, children prefer individualistic experience and tend to watch TV in their bedroom if possible (Saxbe et. al., 2011:184-185). It will be interesting to see whether the integration of the new technologies to TV will change the perception of parents and children.

Tsekleves et. al (2011: 151-161) studied the changing effects of the new technologies on the family members perceptions and the social aspect of TV use in this particular aspect. The most exciting result of this study is that, while comparing the TV with PC, the responders expect the PC's technological features from the TV as well. Most of the responders said that they would like to view their YouTube videos, photos etc. on TV screen. Hence it will not be an excessive comment to claim that the consumers will inquire the social media content of the TV they intend to buy (Tsekleves et. al 2011: 154-160).

The difference between the main motivations of watching analogue TV and smart TV is that of analogue TV is perceived as the source of entertainment and information while smart TV brings social interaction into play. Belman et. al, (2010: 67-87) studied the digital TV watching habits and interaction possibilities. They concluded that the relationship between the digital TV and its users is similar to the social media and its users. They both lead to the similar feelings of relatedness and gratitude (Bellman et. al, 2010: 81-85).

Personalization is another motivation that leads users to switch from analogue to the smart TV. This fact is on the agenda of the recent research projects. Researchers and engineers are building up prototypes to test the personalization functionalities and their user-friendliness as well as the potentials of different applications on this aspect. One of the main tasks for the researchers in the personalization of TV, is to find a way to integrate personalized advertisements on the TV, just like personal web banner ads. One of the best examples for these studies is the literature is reported by López-Nores et. al, in 2011. This study introduces a research on creating a system called MISPOT, which can automatically create digital TV applications that can provide tailored commercial functionalities for users within TV programs. MISPOT's system construction depends on user's demographical data, viewing and consumption history (López-Nores et. al, 2011: 12691-12698).

Montpetit et. al. (2011), investigates the architectural structure of internet television and assess the added value of an IP based TV. The IP technology enables the communication between all the devices of a user. Thus, an IP based TV will offer new opportunities and functionalities. A favorite content chosen by a user on a mobile phone can be accessible through a home TV or it can be transferred to a tablet computer to be used while on vacation. The authors summarize this added value as "anytime, anywhere, any device"

Submit Date: 12.01.2021, Acceptance Date: 01.02.2021, DOI NO: 10.7456/11102100/007

Research Article - This article was checked by iThenticate

Copyright (C) The Turkish Online Journal of Design, Art and Communication 
(Montpetit et. al., 2011: 519-532). Another added value is the sociability made possible by IP and/or new technology-based TVs. Through these facilities, the content can be shared with friends; people who are watching same content simultaneously can exchange comments; by this way there will be new opportunities on the market by means of sociability. This facility is called "social TV". There have been a number of researches on social TV and interaction of people both in the same and different environments are studied (Chorianopoulos \& Lekakos, 2008: 113-120; Montpetit et. al, 2011: 519-532).

Mobile 3D TV and video technologies are also investigated in the context of new opportunities and functionalities. In 2008, Pyykkö et. al claimed that the mobile 3D TV technologies should cover entertainment and information needs of the users with high quality resolution, offer personalized content, present pay-per-view and monthly payment options (Pyykkö et. al, 2008: 189-191)

To generate users' expectations and to fulfill them in the context of the TV technologies and other product design is as challenging as integrating these technologies to the products. There is considerable number of researches the literature offers. The importance of comprehensive approaches and interaction among diverse participants and stakeholders is intensely highlighted, and its claimed that participatory approaches are successful in inspiring knowledge transfer, collective learning and common vision (Warnke, \& Heimeriks, 2008: 85-87). However, traditionally, user surveys and interviews are rarely used to identify the needs or opportunities at early discovery phase of the development practice. Rather, they are widely used in evaluating advanced stages such as concept testing, marketing and adoption. While the potential users of a new technology, their emotional expectations and how their usage behavior will progress are unknown, this information is very important in terms of strategical planning and verdict within the scope of invention research. Thus, in this paper, an empirical study was conducted with potential users with the aim of harmonizing them with their dream TV experience.

\section{Emotions and Product Design}

In the past a proper design in the field of interactive products, was defined by how well it incorporated manufacturing goals and whether the products created were properly functioning or not, while omitting hedonic and pragmatic aspects of interactive goods introduced later. The recent literature puts increasing emphasis on users' emotions, thoughts, environment and circumstances while creating and evaluating design decisions and opportunities (Batra \& Ahtola, 1990: 159-170; Strahilevitz \& Myers, 1998: 434-446; Dhar \& Wertenbroch, 2000: 60-71; Norman, 2004; Hassenzahl \& Tractinsky, 2006: 91-97 ).

Hassenzahl \& Tractinsky (2006: 94) state that users' preference for the design of a product occurs only to the extent that it confirms their expectations, needs, motivations and emotional states. Accordingly, the success of the product is directly related to the environment in which it will be used, as the ability of the consumer to satisfy the desired activities and keep their social relations alive is the fundamental element in the preference of the product (Hassenzahl and Tractinsky, 2006: 95). Similarly, Chitturi, Raghunathan and Mahajan (2008: 61) argue that the consumption experience is driven by emotional content and for that reason designers should discover the hedonic and pragmatic benefits of a product they design.

In an interview published at the interactiondesign.org, Hassenzahl gave a vivid example. He said that a designer who wanted to be successful in his/her work (here the work is design an alarm clock), should ask the user how (s)he wants to wake up, instead of asking her/him what kind of alarm clock (s)he wants to have. With such a method, the goal of the designer and the expectation of the consumer can intersect (URL2, Interaction Design Foundation (interactiondesign.org) - Hassenzahl, 2013: 1-7). In other words, the consumer's willingness to own will emerge by designing the context that leads to that of emotion rather than reflecting the emotion through the existence of the product. Consequently, we can say that today the emotions are being conceived and designed alongside the products.

Submit Date: 12.01.2021, Acceptance Date: 01.02.2021, DOI NO: 10.7456/11102100/007

Research Article - This article was checked by iThenticate

Copyright (C) The Turkish Online Journal of Design, Art and Communication 
In today's consumer electronics market, one can have several options, all of which having similar features at a given price range. The purchase decision is mostly made by judging the emotional appeal, hedonic values and design of the product. In consequence, the consumers' choices are led by their emotional states and previous experiences, as reviewed in the literature.

While the existing literature clearly states that emotions and past user experiences play a major role in product choices, only a few studies tend to measure and spot what emotions are in play and how they intervene. In this sense, Chen et. al, (2012) suggested an alternative process for designer with FASE Index. This index divides contemporary design into four categories (dimensions) including Features, Association, Social-esteem and Engagement. The word FASE refers to these dimensions. While determining this index, literature analysis, open-ended surveys and structured interview methods with professional designers and consumers were used to determine the reasons why consumers are willing to buy a product because of its emotional value. They collected more than 400 statement lines through protocol analysis and questionnaires. The outcomes of the interview were used as facts for a focus group to instruct, choose, and identify items. By this way 13 evaluation criteria or "the essential elements" of proper product design are identified and then associated with the appropriate dimension (Chen \& Chu, 2012: 2011-2020.). These or similar applications can be used as a structure for design communication as well as determining the emotional design evaluation and creation criteria. In other words, the use of FASE index or similar methods can allow designers to design their products according to the (emotionally) expected characteristics and establish the desired communication with users.

Hassenzahl et al (2010: 359-361), while encouraging work on the necessity of designing for a pleasant and good life, examined the key factors that create "pleasurable experiences" regarding technological products and concluded fulfillment of user needs were linked to hedonic and aesthetic needs rather than pragmatic and functional requirements. According to the research, the main features that technological products should include in order to provide a pleasant use by fulfilling the emotional expectations of the users are defined as popularity, relatedness, meaning, security, competence, encouragement and autonomy.

Desmet (2008: 391-404) defined 14 emotions divided equally into positive and negative emotions that are triggered by the users while in interaction with products. In order to measure emotional responses from users, Desmet provided a self-reporting tool "the PrEmo" consisting in animated icons associated to the emotions, providing a universal and objective measurement. The icons selected by the users can than lead designers in their work (Desmet, 2008: 391-404); Demir et al. 2009: 41-51.).

It is seen that while considering all (utilitarian and hedonic) features in product design, understanding why some features of a product trigger certain emotions is very important in terms of customer satisfaction and pleasure today. This understanding will lead us to a strategical design process where we can understand the expectations of the users and create well-designed smart products.

\section{EMPIRICAL STUDY}

This study aims to examine the user habits and behaviors towards the continuously changing TV culture, in order to appraise the expectations and understand which features should be included in a smart TV. To this aim, this paper focuses on the following questions:

1. In which activity, in what context and how are the users want to interact with TV? What do they want to experience from TV?

2. Which positive emotions do satisfy (feed) which expectations, which negative emotions prevent satisfaction, and why those particular emotions do arouse?

3. What kind of product qualities influences emotional responses?

Submit Date: 12.01.2021, Acceptance Date: 01.02.2021, DOI NO: 10.7456/11102100/007

Research Article - This article was checked by iThenticate

Copyright (C) The Turkish Online Journal of Design, Art and Communication 


\section{Sample}

The selected participants have different backgrounds. The total number of participants is set to 11 males and 9 females. The inclusion criterion for this sample group is their habit of television viewing which is at least 1-2 hours per day, mainly 3-4 hour or more. The number of male and female participants tried to be maintained equal in order to homogenize the sample. The results shown in this study are based on data collected from all participants.

\section{Data Collecting Procedure}

The literature review and emotional measurement tools were used as a basis to develop interview questions. We used items from previous studies of product design, such as PrEmo (Desmet, 2003, 2018) that identifies 14 emotions divided equally into positive and negative emotions that are most frequently elicited during interaction. Firstly, the identified emotions depicted from Desmet's research are translated into Turkish, which is the native language of the sample group. Secondly, emotion cards were designed for randomizing the interview flow. Thirdly, the participant is engaged to pick up any card of his/her choice and according to his/her arrangement of the cards a semi-structured in-depth interview was conducted to reveal his/her activity, experience, and emotional commitment, expectations from the TV using experience. The below table (1) shows mentioned emotions and related questions follows with figure (1) which shows the emotional cards used during the in-depth interviews.

\begin{tabular}{|c|c|}
\hline EMOTIONS & RELATED QUESTIONS \\
\hline Desire & $\begin{array}{l}\text { What would you desire from your dream TV? } \\
\text { How would be the most desirable TV? } \\
\text { Can you explain a desirable TV? Why? }\end{array}$ \\
\hline Hope & $\begin{array}{l}\text { What do you hope for your dream TV? } \\
\text { How can a TV be hope-rising? } \\
\text { Can you think of a hope-rising TV usage scenario? }\end{array}$ \\
\hline Pride & $\begin{array}{l}\text { How can a TV provoke pride in you? Can you explain? } \\
\text { What a TV must have to make you proud? }\end{array}$ \\
\hline Joy & $\begin{array}{l}\text { What would a TV have to be joyful? } \\
\text { Can you identify a joyful TV? }\end{array}$ \\
\hline Admiration & $\begin{array}{l}\text { What should a TV have to be to raise admiration in you? } \\
\text { Would you admire a TV? } \\
\text { Please define an admirable TV to us. }\end{array}$ \\
\hline Satisfaction & $\begin{array}{l}\text { What your dream TV must have to satisfy you? } \\
\text { How you would be satisfied by a TV experience? }\end{array}$ \\
\hline Fascination & $\begin{array}{l}\text { What fascinates you about a TV? } \\
\text { How would be a fascinating TV? Please explain? }\end{array}$ \\
\hline Boredom & $\begin{array}{l}\text { What about a TV bores you? } \\
\text { If TV has a.... it will be so boring. } \\
\text { Can a dream TV bore you? }\end{array}$ \\
\hline Dissatisfaction & $\begin{array}{l}\text { What might dissatisfy you about a TV? } \\
\text { How can your dissatisfaction, if happens, can be eliminated in a TV experience? }\end{array}$ \\
\hline Contempt & How can TV contempt you? \\
\hline
\end{tabular}

Submit Date: 12.01.2021, Acceptance Date: 01.02.2021, DOI NO: 10.7456/11102100/007

Research Article - This article was checked by iThenticate 


\begin{tabular}{|l|l|}
\hline \multirow{2}{*}{ Sadness } & Can you think of a contemptible TV usage scenario? \\
\hline Shame & $\begin{array}{l}\text { What makes you sad about TV? } \\
\text { How might be a sad TV? }\end{array}$ \\
\hline Fear & $\begin{array}{l}\text { May you be shame of a TV? } \\
\text { How may be a shameful TV? }\end{array}$ \\
\hline Disgust & $\begin{array}{l}\text { How will TV make you frighten? } \\
\text { Can be a frightening experience with a TV? }\end{array}$ \\
\hline
\end{tabular}

Table 1: Emotions and related questions.
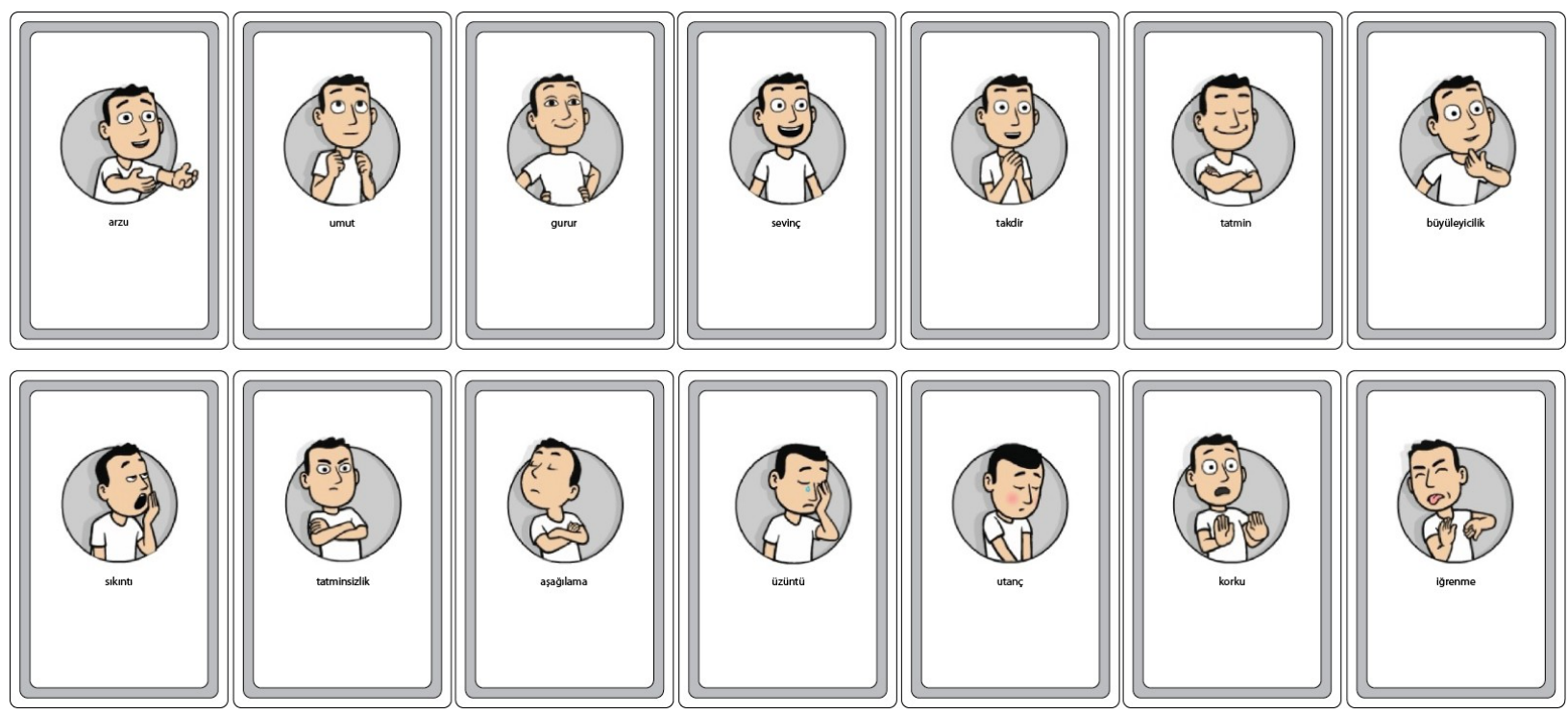

Figure 1: Emotion cards.

\section{Interview Flow}

Interviews start with some basic information about current innovations and technologies on smart TV sector. Examples of current smart TV products follow as talking about Samsung's prototype electronic device capable of producing a variety of scents that is small enough to fit behind or under a TV. Continuing example is chairs that are connected with TV, so that while watching motorsport from an onboard camera, a viewer's chair could lean into corners, increasing the feeling of ride with the driver. Lastly, 3D TV and Hologram technologies are also mentioned.

The reason of giving such examples and information is to ask interviewees about their dream TV and continuing the conversation on their possible emotions towards a non-produced and non-existent dream object. However, the interview is planned around randomized semi-structured questions on their emotions towards TV. All the interviews started with a question about the dream TV of the participant. The interviewee is invited to specify how would his/her dream TV will be, which features should it include, and why? In-depth interviews have been conducted within this framework (figure 2).

Research Article - This article was checked by iThenticate 

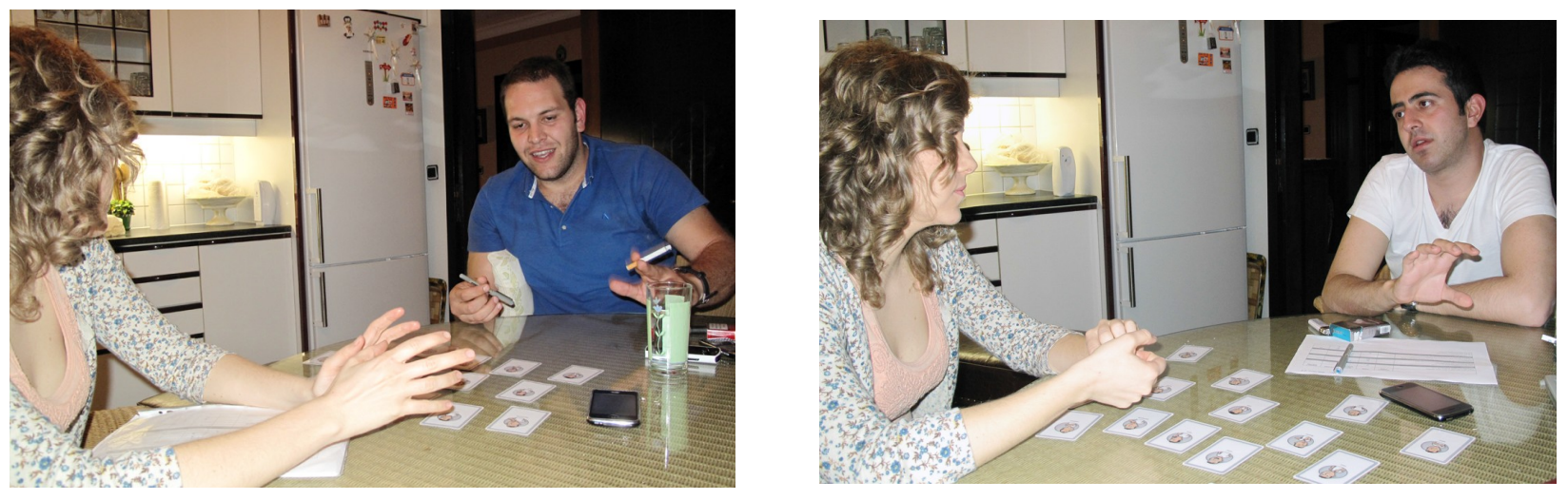

Figure 2: Interview. (Photos used with the informed consent of the participants)

\section{Data Analysis Procedure}

Data collected through semi-structured in-depth interviews are used in the research to gather the qualitative data. Content analysis method, which can be used in analyzing both qualitative and quantitative data, but especially common in analyzing data to make inferences from the text, suits well with in-depth interview analysis procedure and therefore it is suitable for this research. By content analysis categorizing data into common categories or groups of similar entities, identify consistent patterns, and finding relationships between variables becomes possible.

To create patterns and clusters, data needed to be inductively analyzed and coded. For this reason, user speeches from interviews are typed as transcript and coded as emotion, expectation, underlying desire and requirement as shown in table (2). After categorizing the data, relationship between each code (as emotion, expectation, underlying desire and requirement) can be easily seen. By this way it becomes possible to make some inference about users' expectations and offer a guideline.

\begin{tabular}{|l|l|l|l|l|}
\hline Emotion & Related Statement & Desire (Underlying) & Expectation & Requirement \\
\hline Fear & $\begin{array}{l}\text { My biggest fear is heavy load of } \\
\text { radiation, energy consumption, and } \\
\text { the harm that it gives to our heath. If } \\
\text { there would be a non--- radiation TV } \\
\text { or at least if it informs me about the } \\
\text { energy it consumed, I will buy that } \\
\text { TV. }\end{array}$ & Health awareness & Aware TV & $\begin{array}{l}\text { Health } \\
\text { awareness } \\
\text { technology/ } \\
\text { energy efficient } \\
\text { technology }\end{array}$ \\
\hline
\end{tabular}

Table 2: Data analysis procedure example.

\section{FINDINGS}

Findings of the analysis will be presented by elaborating expectations, highlighting underlying desire with providing some quotations from the participants and finally exemplifying relationships between desires, expectations and emotions. Findings aim to identify the most basic or fundamental motives in other words find meanings of TV for users and provide a guide on how to address those meanings by design.

\section{Dimensions of Expectations from TV Experience}

Data analysis shows that main user expectations can be grouped under fourteen categories; these are as follows in alphabetical order. Appealing TV, aware TV, compatible TV, enjoyable TV, functional TV, high quality TV, novel interaction TV, personalized TV, portable TV, self-defense TV, smart TV, user-friendly TV, voice remote TV, warning TV. Some of these categories have been mentioned explicitly by the responders, some others are named by the researcher according to the definitions of the interviewees. In the

Submit Date: 12.01.2021, Acceptance Date: 01.02.2021, DOI NO: 10.7456/11102100/007

Research Article - This article was checked by iThenticate

Copyright (C) The Turkish Online Journal of Design, Art and Communication 
following sections of this paper, these categories have been phrased as product features expected from the design of a TV.

Appealing TV: Appealing TV refers to aesthetic appearance of the TV. Aesthetic appeal mostly indicates what extent products or interface of the products is found pleasing. In this study, it implicates user's aesthetic insights related to the design of the product in terms of size, dimension, color, shape etc. and attractiveness in providing visual information and interaction.

Aware TV: In this study, aware TV refers to awareness towards environmental consciousness and health issues. It indicates TV's software's ability to be aware of environment and health issues and notifies the user by providing related information.

Compatible TV: Compatible TV refers to compatible units, which allow unproblematic direct communication with each other. Mostly in TV experience it implies to cloud or wireless communication between TV, audio system, DVD, BLU-Ray etc.

Enjoyable TV: Enjoyable TV is named so as to imply a TV, which creates fun and enjoyment during its usage in various ways.

Functional TV: In this paper Functional TV infers to TV's adequate user---friendly functions that enable successful usage pattern which users are motivated and achieve their goals.

High Quality TV: In general, participants in this study refer to high Quality of TV by evaluating its sound and screen resolution quality.

Novel Interaction TV: This term refers to innovative interactions ability to engage viewer to content either by $3 \mathrm{D}$ or hologram technology.

Personalized TV: In this study, personalized TV implies a TV that enables users to personalize both content and information by screen interaction.

Portable TV: It infers to a TV experience that helps users to access any content, anyplace, anytime effortlessly.

Self---Defense TV: Self---defense TV refers to TV's software ability to provide self---maintenance and enable long---term trouble---free usage.

Smart TV: Smart TV relates to the user's beliefs of a TV, which would enhance his or her expectations. Participants associate smart TV with number of features. Common related features are, easy and efficient usage, low error rate, pleasant usage experience and user---friendliness.

User-Friendly TV: Refers to software with a simple and smart language help user make decisions on what to consume and demand minimal effort.

Voice Remote TV: Refers to a TVs satisfactory remote control that supports voice recognition technology. Data analysis show that users desire of remote control mostly associates with a remote that can be easily used by voice for providing effective battery free simplified usage.

Warning TV: Warning TV associates with software able to provide feedback and notifications about users' past usage patterns and behaviors, such as watching length, most preferred channel, etc.

Sequencing comments made on dream television expectations, which have highest frequency, are smart $T V$, High quality TV, Personalized TV, Functional TV and Appealing TV. Underlying desires and emotions for these comments will be explained in detail and required technology will be suggested. The distribution of comments accordance with all expectations is shown in the table below (3).

Submit Date: 12.01.2021, Acceptance Date: 01.02.2021, DOI NO: 10.7456/11102100/007

Research Article - This article was checked by iThenticate

Copyright (C) The Turkish Online Journal of Design, Art and Communication 


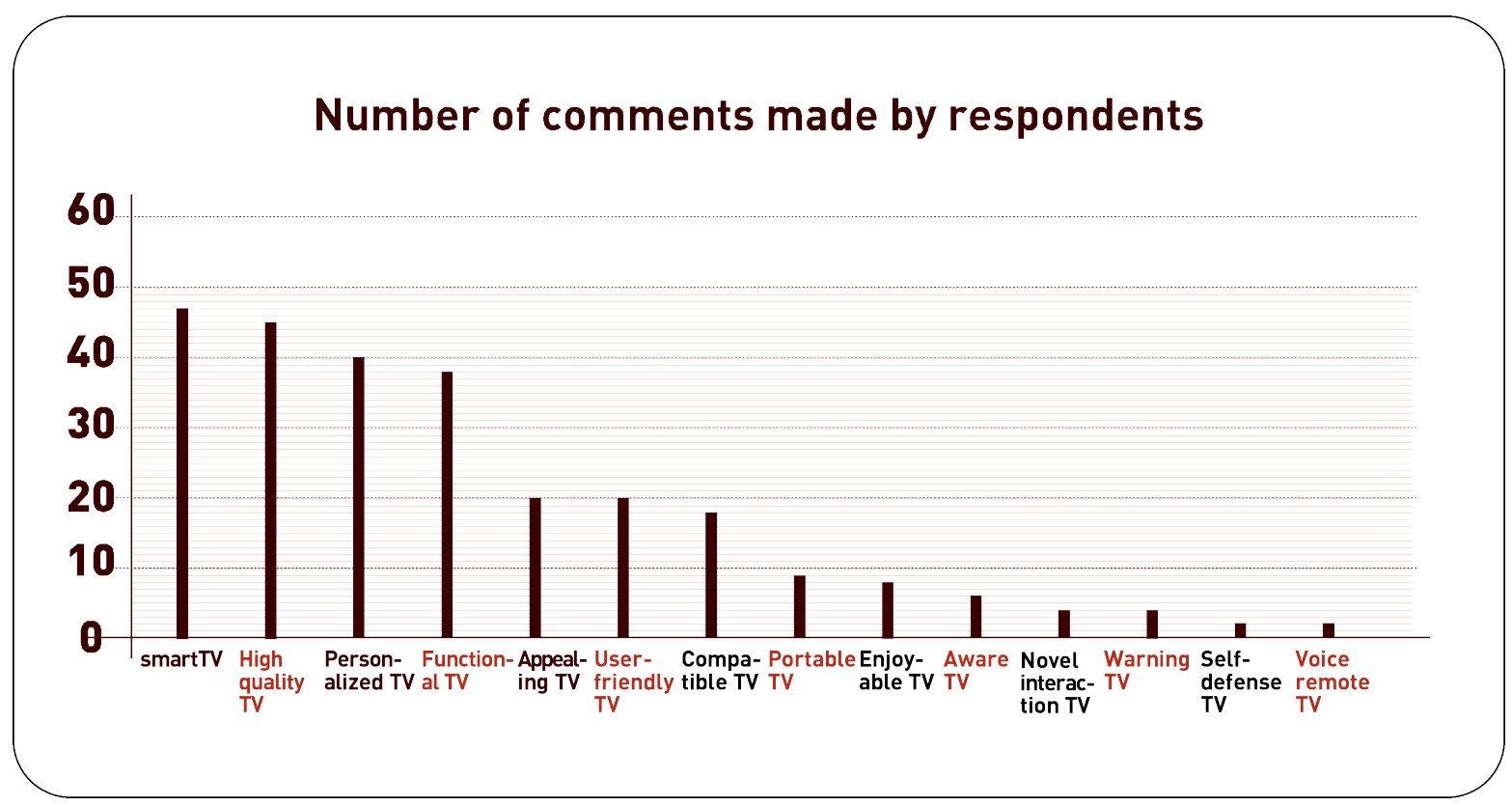

Table 3: Distribution of comments given by the respondents according to their expectation of dream TV.

\section{Highest Mentioned Expectations}

\section{Smart TV}

Most participants related smart TV with a TV that has smart interaction and software by means of usefulness, adaptability, recognition and compatible units. It represents to what extend a TV can know who it is interacting with and makes that of user's life easier and meaningful. The emotions related to that expectation could be range as admiration, joy, satisfaction and fascination. To give an example participants state that;

- It would very helpful if I would be able to tell the channel I want to view and it recognize. Moreover, I want to tell the content not the channel or even ask a question like; can you find me a movie that I want on Saturday night? I would definitely love it. P5

- If it could recognize that I fall asleep and automatically turn the sound down and slowly shut down, which means if it helps me to sleep, I would be so happy. P12

- What do you want to watch? That is the question I would like my TV to ask to me like a friend. If then it displays me alternatives it would be perfect. P7

- I want it to allow me to effortlessly accomplish behaviors that I do. P11

\section{High Quality TV}

High quality TV is second most frequently released expectation. This expectation is related with high quality display and sound that meets the user expectations and affordable by means of price. Also, users indicate a need of high-quality screen resolution for enjoyably playing game. Another underlying desire for high quality TV is sustainability and trouble--free experience, which would provide long usage period. Mainly users indicate desire of properly functioning long-lasting TV experience by stating;

- I feel humiliated when I did not receive good value equivalent to money I give. This is a fact. P3

- If it doesn't not meet specifications that were promised in other words unable to satisfy, to say, if the expectation from the audio and video quality does not meet the forecasted value, it is saddening. I will be sad. Maybe there can be trial period. So at least you can imagine. Maybe trial period will prevent us from such situation. P19 
- After I bought a TV I don't want to deal with any technical problem. My desire is unbreakable properly working long-lasting TV. P12

- All the technological problems should be solved viewing must be without interruption. Technically big screen is also very important point and also sound system should be satisfactory. P4

\section{Personalized TV}

It seems personalization is related with personalized content viewing, not missing content, saving time and allowing viewing without ad interruption. Ultimately participants appreciate functions that make life easy for them and enable them to save time while support all of these functions with a tailor-made personalization. However, it seems very important to notice confidentiality thus user meet on common ground in confidentiality issues. Since participants consider privacy setting as a must. Sadness, disgust, dissatisfaction and shame are the related emotions towards the break of confidentiality. For instant two participants stated;

- I would be better select 5---6 channels and view only them. If I do not see channels unrelated to my preference it would eliminate zapping channels, which would probably reduce dissatisfaction with the publication. P12

- I don't want exist in a world where everything is open to everyone. Some things will be confidential. I don't want to share any information about me and extract any information from my other accounts. Information about my usage pattern and usage history must be only between my TV and me. P1

\section{Functional TV}

The need of functional TV is mostly associated with enjoyment and ease of use users expects functions that can utilize all kinds of usage. They desire a functional TV permitting laziness, comfortableness such as having Internet connection without connecting with computer. While users are looking for facilitating those expectations, they also mentioned an ever--- evolving smart software that enables new functionalities by updates. One of participant points the expectation by saying;

- I want to do my jobs easily and all at once, I want everything at my fingertips. P5

\section{Appealing TV}

It seems that appealing is related mostly with the appearance of TV. It refers to design's uniqueness and seamlessness. Participants frequently stated a desire of having a TV that fit the design of the house, which means design wise there is a need of more options. Some participants said that they would prefer a simple even seamless design that wouldn't disturb them while watching the content. Additionally, appealing TV frequently mentioned with relation to large screen size. One participant express desire on appealing TV by stating;

- Design is important because it focuses or defocuses attention on the content. I would rather want a seamless design that enables me to follow the content. Apart from that while TV is off it also shouldn't take attention and ruin the overall design of the environment. P6

\section{Relationship Amongst Expectations, Underlying Desires, Emotions and Requirements}

For offering interpretation on design and technology for a Smart TV product, it is important to see what kind of expectations are associated with what kind of underlying desires and which emotion creates such an expectation. After all, for designer and producer consequences can be considered as design requirements. Following table (4) clarifies this complex relationship between all those expectations, desires (underlying needs) and emotions. Below there is a diagram (4) that can be both read from point of underlying needs or emotions cause that need. By this way it can be a guideline to fit a design and product that fulfills user expectations. 
The Turkish Online Journal of Design, Art and Communication - TOJDAC

ISSN: 2146-5193, April 2021 Volume 11 Issue 2, p.424-442

\begin{tabular}{|c|c|c|c|}
\hline EXPECTATION & UNDERLYING NEED & EMOTION & REQUIREMENTS \\
\hline Smart TV & $\begin{array}{l}\text { - Novel user experience. } \\
\text { - Novel interaction offering a } \\
\text { content/talking TV/TV giving } \\
\text { suggestions } \\
\text {-Effortless usage experience } \\
\text {-Easily share content between devices } \\
\text {-To grow lazy } \\
\text {-Portable compatible usage } \\
\text {-Enabling social interaction } \\
\text {-Confidentiality } \\
\text {-Ever-evolving technology } \\
\text {-Makes life easy } \\
\text {-Understandability, simplicity }\end{array}$ & $\begin{array}{l}\text { Admiration (4) } \\
\text { Boredom (4) } \\
\text { Dissatisfaction (3) } \\
\text { Fascination (3) } \\
\text { Joy (3) } \\
\text { Shame (3) } \\
\text { Disgust (2) } \\
\text { Hope (2) } \\
\text { Satisfaction (2) } \\
\text { Contempt (1) } \\
\text { Desire (1) } \\
\text { Fear (1) } \\
\text { Sadness (1) }\end{array}$ & $\begin{array}{l}\text { - Voice recognition } \\
\text {-Smart interaction } \\
\text {-Embedded functions } \\
\text {-Hologram and 3D } \\
\text { technology } \\
\text {-Multi-functional remote } \\
\text { control } \\
\text {-Cloud communication } \\
\text {-Fine details. } \\
\text {-Compatibleness } \\
\text {-Connectivity /direct internet } \\
\text { connection. } \\
\text {-Privacy settings } \\
\text {-Embedded battery / } \\
\text { electricity free usage } \\
\text { - Notifications }\end{array}$ \\
\hline High Quality TV & $\begin{array}{l}\text {-To be fascinated } \\
\text {-High screen resolution for game } \\
\text {-Feeling content more } \\
\text {-Novel display experience } \\
\text {-Properly functioning TV } \\
\text {-Meet expectations worth the price } \\
\text {-Effortless usage experience } \\
\text {-Sustainability long usage period } \\
\text {-Not affecting from external factors } \\
\text {-Trouble-free experience }\end{array}$ & $\begin{array}{l}\text { Sadness (8) } \\
\text { Contempt (5) } \\
\text { Boredom (3) Pride (3) } \\
\text { Satisfaction (3) } \\
\text { Shame (3) } \\
\text { Admiration (2) } \\
\text { Dissatisfaction (2) } \\
\text { Fascination (2) } \\
\text { Fear (2) } \\
\text { Disgust (1) } \\
\text { Hope (1) } \\
\text { Joy (1) }\end{array}$ & $\begin{array}{l}\text {-Sound and display } \\
\text { technology } \\
\text {-Affordable high quality } \\
\text {-HD resolution//Retina } \\
\text { display } \\
\text {-Smart software } \\
\text {-High quality satisfy the } \\
\text { expectation } \\
\text {-Adequate technology } \\
\text {-Multi-functionality }\end{array}$ \\
\hline Personalized TV & $\begin{array}{l}\text {-To grow lazy (easily doing everything) } \\
\text {-Not to miss content } \\
\text {-Personalized content viewing. } \\
\text {-TV knows my mood and suggests } \\
\text { content } \\
\text {-Effortless usage experience } \\
\text {-Confidentiality } \\
\text {-More channels } \\
\text {-Making life easy } \\
\text {-Allowing viewing without ad } \\
\text { interruption } \\
\text {-Allowing personal content viewing while } \\
\text { together } \\
\text {-Save time }\end{array}$ & $\begin{array}{l}\text { Sadness (8) Disgust (7) } \\
\text { Dissatisfaction (3) } \\
\text { Satisfaction (3) } \\
\text { Shame (3) } \\
\text { Admiration (2) } \\
\text { Boredom (2) } \\
\text { Desire (2) } \\
\text { Dream TV (2) } \\
\text { Fear (1) } \\
\text { Hope (1) } \\
\text { Joy (1) } \\
\text { Pride (3) }\end{array}$ & $\begin{array}{l}\text {-Personalization } \\
\text {-Pre-recording technology } \\
\text {-Content filtering } \\
\text {-Smart interaction///smart } \\
\text { software } \\
\text {-More channels } \\
\text {-Privacy settings } \\
\text {-Adequate technology } \\
\text {-Novel functionalities }\end{array}$ \\
\hline Functional TV & $\begin{array}{l}\text {-Enjoyment and easily use } \\
\text {-Effortless usage experience } \\
\text {-To grow lazy } \\
\text {-Utilize all kinds of usage } \\
\text {-Comfortableness } \\
\text {-Enabling to do outside activities at home }\end{array}$ & $\begin{array}{l}\text { Disgust (7) } \\
\text { Dissatisfaction (7) } \\
\text { Hope (6) } \\
\text { Pride (6) } \\
\text { Admiration (5) } \\
\text { Desire (3) }\end{array}$ & $\begin{array}{l}\text {-Adequate technology } \\
\text {-Embedded functions } \\
\text {-Novel /utilitarian functions } \\
\text {-Smartness /intelligence } \\
\text {-Innovative software/system. } \\
\text {-Smart interaction/smart } \\
\text { software }\end{array}$ \\
\hline
\end{tabular}

Submit Date: 12.01.2021, Acceptance Date: 01.02.2021, DOI NO: 10.7456/11102100/007

Research Article - This article was checked by iThenticate

Copyright (C) The Turkish Online Journal of Design, Art and Communication 
The Turkish Online Journal of Design, Art and Communication - TOJDAC

ISSN: 2146-5193, April 2021 Volume 11 Issue 2, p.424-442

\begin{tabular}{|c|c|c|c|}
\hline & $\begin{array}{l}\text {-Making life easy } \\
\text {-Enabling internet without connecting } \\
\text { with computer } \\
\text {-Time saving } \\
\text {-TV knows my mood and suggests } \\
\text { content } \\
\text {-Ever-evolving/improving itself always } \\
\text { new functions } \\
\text {-Confidentiality } \\
\text {-More channels } \\
\text {-Novel functionalities do all jobs } \\
\text {-TV knows my mood and suggests } \\
\text { content } \\
\text {-Effortlessly done technology related jobs } \\
\text { on large screen. } \\
\text {-Save time } \\
\text {-Meet expectations worth the price } \\
\text {-Continuous experience without getting } \\
\text { out of order } \\
\text {-Practical usage }\end{array}$ & $\begin{array}{l}\text { Dream TV (3) } \\
\text { Fascination (3) } \\
\text { Joy (3) } \\
\text { Sadness (3) } \\
\text { Satisfaction (3) } \\
\text { Shame (3) } \\
\text { Boredom (2) } \\
\text { Fear (1) }\end{array}$ & $\begin{array}{l}\text {-Smart production/Fine } \\
\text { details. } \\
\text {-Pre-recording technology } \\
\text {-Usability } \\
\text {-Embedded channels/ more } \\
\text { content availability } \\
\text {-Voice recognition }\end{array}$ \\
\hline Appealing TV & $\begin{array}{l}\text {-Having unique design } \\
\text {-To focus on following content } \\
\text {-Seamless Design } \\
\text {-Not changing the design of the house } \\
\text {-Large screen size } \\
\text {-Aesthetic appeal } \\
\text {-Fit the design of the house } \\
\text {-Aesthetic appeal }\end{array}$ & $\begin{array}{l}\text { Dream TV (3) } \\
\text { Fascination (3) } \\
\text { Desire (2) } \\
\text { Satisfaction (2) } \\
\text { Contempt (1) }\end{array}$ & $\begin{array}{l}\text {-Design variations } \\
\text {-Adequate technology }\end{array}$ \\
\hline $\begin{array}{l}\text { Compatible } \\
\text { Functions/ } \\
\text { Units TV }\end{array}$ & $\begin{array}{l}\text {-Effortless/convenient usage } \\
\text {-Wireless compatible units } \\
\text {-Pleasurable usage experience } \\
\text {-Anywhere, anytime any content. } \\
\text {-To grow lazy (easily does everything) } \\
\text {-Directly play online games } \\
\text {-Effortless/convenient game play } \\
\text {-Making life easy } \\
\text {-Effortlessly done many technology } \\
\text { related jobs on large screen. } \\
\text {-Effortless/convenient usage experience }\end{array}$ & $\begin{array}{l}\text { Desire (2) } \\
\text { Dream TV (2) Hope (2) } \\
\text { Admiration (1) } \\
\text { Fascination (1) } \\
\text { Joy (1) } \\
\text { Satisfaction (1) }\end{array}$ & $\begin{array}{l}\text {-Connectivity and } \\
\text { compatibleness } \\
\text {-Wireless technology } \\
\text {-Cloud communication } \\
\text {-Embedded functions }\end{array}$ \\
\hline Portable TV & $\begin{array}{l}\text {-To reach personal content anywhere, } \\
\text { anytime. } \\
\text {-Not to put a TV everywhere } \\
\text {-To use any surface as screen and access } \\
\text { content at any place any surface. }\end{array}$ & $\begin{array}{l}\text { Desire (3) } \\
\text { Dream TV (2) }\end{array}$ & $\begin{array}{l}\text {-IP number / cloud } \\
\text { communication } \\
\text {-Portable TV technology } \\
\text {-Screen share technology } \\
\text {-Adequate technology }\end{array}$ \\
\hline Enjoyable TV & $\begin{array}{l}\text {-To easily play games on TV } \\
\text {-For fun } \\
\text {-Novel interaction/ user experience for } \\
\text { enjoyment. } \\
\text {-Encourage me with my good habits }\end{array}$ & $\begin{array}{l}\text { Joy (3) } \\
\text { Dream TV (2) } \\
\text { Hope (1) } \\
\text { Pride (1) }\end{array}$ & $\begin{array}{l}\text {-Embedded game console } \\
\text {-Digital editing function } \\
\text { - Smart software and smart } \\
\text { interaction } \\
\text { - Touch screen technology } \\
\text { - Embedded functions/ }\end{array}$ \\
\hline
\end{tabular}

Submit Date: 12.01.2021, Acceptance Date: 01.02.2021, DOI NO: 10.7456/11102100/007

Research Article - This article was checked by iThenticate

Copyright (C) The Turkish Online Journal of Design, Art and Communication 
The Turkish Online Journal of Design, Art and Communication - TOJDAC

ISSN: 2146-5193, April 2021 Volume 11 Issue 2, p.424-442

\begin{tabular}{|c|c|c|c|}
\hline & $\begin{array}{l}\text {-Knows who I am and suggest me } \\
\text { accordingly } \\
\text {-Novel experiences }\end{array}$ & & Connectivity \\
\hline Aware TV & $\begin{array}{l}\text {-Health awareness } \\
\text {-Energy awarenes }\end{array}$ & $\begin{array}{l}\text { Disgust (2) } \\
\text { Fear (2) } \\
\text { Admiration (1) } \\
\text { Boredom (1) }\end{array}$ & $\begin{array}{l}\text {-Health aware technology } \\
\text { - Low energy consume }\end{array}$ \\
\hline Novel interaction TV & $\begin{array}{l}\text {-Allowing all sense interaction } \\
\text {-Novel interaction/ user experience }\end{array}$ & $\begin{array}{l}\text { Dream TV (2) } \\
\text { Admiration (1) } \\
\text { Boredom (1) } \\
\text { Desire (1) } \\
\text { Hope (1) }\end{array}$ & $\begin{array}{l}- \text { Hologram technology } \\
-3 \mathrm{D} \text { technology without } \\
\text { glasses }\end{array}$ \\
\hline Self-defense TV & -Properly functioning & Fear (2) & -Self-maintenance \\
\hline Voice -remote TV & $\begin{array}{l}\text {-Easily manage } \\
\text {-Effortless usage experience }\end{array}$ & $\begin{array}{l}\text { Desire (1) } \\
\text { Fascination (1) }\end{array}$ & $\begin{array}{l}\text {-Voice recognition } \\
\text { technology }\end{array}$ \\
\hline
\end{tabular}

Table 4: Relationship between expectations, desires (underlying needs) and emotions.

\section{CONCLUSION}

Single function, closed system products are disfavored in today's world of technology. Young people stopped wearing watches. TV, which was once the focus of our domestic lives, has been reconsidered with respect to its limited functions. The functionalities that PCs, mobile phones, Internet and social media offer have surpassed what TV provide us. The future of the TV is either passing beyond being only a mass communication device or taking its place in the 20th century technology museum. The recent developments indicate that designers and manufacturers are not ready to let TV go; so, a new concept, namely smart TV is introduced. Smart TV is expected to be a multi-function, personalized device, which will assist and accompany its user.

Although the concept is appealing, there are still an immense need for comprehensive research on what the smart TV should look like, with what content and functionalities. The forerunners of smart TV are on the market; those pioneers contain new technologies and open up new horizons for the designers. On the other hand, consumers' expectations and demands have not been quite determined yet. At this point there is a huge research work to be done. The increasing number of the research articles in the recent literature on this subject is the evidence of increasing comprehension of the fact.

This study aims to provide insights in the area of smart TVs, by revealing the visions of participants about what a dream TV should be like. It is conducted as a field research. Data collected through semi-tructured in-depth interviews.

Our findings conform to the findings of the other researchers in general. As it is analyzed herein, since available information mainly communicated on the Internet, personal TV experience choices are becoming the norm, rather than exceptions. People do not want a classical mass media device that dictates its content and time schedule on them; but rather a means that is sensitive to their needs and pleasure. They are not satisfied with the information flow through an impersonalized origin in an anonymous manner; but rather a personalized sum of information that they can share with significant others. They want to be a part of the product and designate the content.

This study, showed that that participants had a tendency to prefer features that required minimal efforts to make decisions on what to consume. Participants' inclination focuses on not choosing from a whole range of options, but rather they prefer products and/or services that are fully tailored according to their needs.

Submit Date: 12.01.2021, Acceptance Date: 01.02.2021, DOI NO: 10.7456/11102100/007

Research Article - This article was checked by iThenticate

Copyright (C) The Turkish Online Journal of Design, Art and Communication 
In addition to the needs, our participants put a great emphasis on the contribution of the TV experience to their pleasure and happiness, as it is claimed in Hassenzahl and Desmet's study. Some of the participants connected this expectation with TV's contribution to their recently existing habits, such as playing digital games, participating in on line competition. Some others' expectations are much more complicated to understand, because they were not concrete, like getting rid of remote-control device they frequently misplaced or that runs out of battery; but rather experience a state of mind or an emotion, such as satisfaction, happiness or tranquility. They value their interaction with TV and want to realize it differently. They want not only communicate through the product but with it as well. The key word in this relation can be userfriendliness and software management. A couple of participants defined voice remote as an option, while some others prefer touch screen.

Our results differ from that of Saxbe's, Bellman's and Tsekleves', because our interviewees did not underline the "sociability" as much as they claimed. But this can be explained by the difference between our main question and theirs.

We need a better understanding of key factors which induce positive user experiences and expectations, we hope this study can enlighten us towards this direction, providing an outline to restructure our knowledge about user expectations, experiences and emotions in a proper way.

\section{Limitation}

This study involves 20 participants who watch TV for at least 1-2, usually 3-4 hours a day, which may not be adequate to make any generalization. Therefore, longitudinal study may be conducted on this subject matter with emotionally connected people who spend more time watching TV. Also, we did not address the connection with demographic characteristics such as gender, wealth, lifestyle of the participants with their answers which is apparently important.

Secondly, emotions defined by Desmet are usually determined according to measure of fourteen emotions which are often evoked in product design. In this regard in some cases participants found that of emotions non-related or inadequate. For further development of this study a pre-study may be carried out for revealing emotions that are often elicited by TV experience rather than product design and results may be added to 14 emotions or some might be omitted.

Lastly, it is well known that imagining something from scratch can be difficult and thus could result inaccuracies in the account of requirements. For future references, a prototype can be used.

\section{REFERENCES}

Batra, R., \& Ahtola, O. T. (1991). Measuring the hedonic and utilitarian sources of consumer attitudes. Marketing letters, 2(2), 159-170.

Bellman, S., Schweda, A., \& Varan, D. (2010). The importance of social motives for watching and interacting with digital television. International Journal of Market Research, 52(1), 67-87.

Berker, T. (2005). Domestication of media and technology. McGraw-Hill Education (UK).

Cesar, P., \& Chorianopoulos, K. (2008). Interactivity and user participation in the television lifecycle: creating, sharing, and controlling content. Proceedings of the 1st international conference on Designing interactive user experiences for TV and video, 125-128.

Chen, L. C., \& Chu, P. Y. (2012). Developing the index for product design communication and evaluation from emotional perspectives. Expert Systems with Applications, 39(2), 2011-2020.

Chitturi, R., Raghunathan, R., \& Mahajan, V. (2008). Delight by design: The role of hedonic versus utilitarian benefits. Journal of marketing, 72(3), 48-63.

Submit Date: 12.01.2021, Acceptance Date: 01.02.2021, DOI NO: 10.7456/11102100/007

Research Article - This article was checked by iThenticate

Copyright (C) The Turkish Online Journal of Design, Art and Communication 
Chorianopoulos, K., \& Lekakos, G. (2008). Introduction to social TV: Enhancing the shared experience with interactive TV. Intl. Journal of Human-Computer Interaction, 24(2), 113-120.

De Moor, K., Saritas, O., Schuurman, D., Claeys, L., \& De Marez, L. (2014). Towards Innovation Foresight: Two empirical case studies on future TV experiences for/by users. Futures, 59, 39-49.

Demir, E., Desmet, P. M., \& Hekkert, P. (2009). Appraisal patterns of emotions in human-product interaction. International journal of design, 3(2), 41-51.

Desmet, P. (2003). Measuring emotion: Development and application of an instrument to measure emotional responses to products. In Funology (pp. 111-123). Springer, Dordrecht.

Desmet, P. (2018). Measuring emotion: Development and application of an instrument to measure emotional responses to products. In Funology 2 (pp. 391-404). Springer, Cham.

Desmet, P., \& Hassenzahl, M. (2012). Towards happiness: Possibility-driven design. In Human-computer interaction: The agency perspective (pp. 3-27). Springer, Berlin, Heidelberg.

Dhar, R., \& Wertenbroch, K. (2000). Consumer choice between hedonic and utilitarian goods. Journal of marketing research, 37(1), 60-71.

Gobé, M. (2010). Brandjam: Humanizing brands through emotional design. Simon and Schuster.

Hassenzahl, M., \& Tractinsky, N. (2006). User experience-a research agenda. Behaviour \& information technology, 25(2), 91-97.

Hassenzahl, M., Diefenbach, S., \& Göritz, A. (2010). Needs, affect, and interactive products-Facets of user experience. Interacting with computers, 22(5), 353-362.

Jumisko-Pyykkö, S., Weitzel, M., \& Strohmeier, D. (2008, October). Designing for user experience: what to expect from mobile 3D TV and video?. In Proceedings of the 1st international conference on Designing interactive user experiences for TV and video, 183-192.

Kaptelinin, V. (2003). Learning with artefacts: integrating technologies into activities. Interacting with Computers, 15(6), 831-836.

Kaptelinin, V., \& Nardi, B. A. (2006). Acting with technology: Activity theory and interaction design. MIT press.

Kaptelinin, V., Nardi, B. A., \& Macaulay, C. (1999). Methods \& tools: The activity checklist: a tool for representing the "space" of context. interactions, 6(4), 27-39.

López-Nores, M., Blanco-Fernández, Y., Pazos-Arias, J. J., Fernández-Vilas, A., \& Ramos-Cabrer, M. (2011). Automatic provision of personalized e-commerce services in Digital TV scenarios with impermanent connectivity. Expert Systems with Applications, 38(10), 12691-12698.

Montpetit, M. J., Klym, N., \& Mirlacher, T. (2011). The future of IPTV Connected, mobile, personal and social. Multimedia Tools and Applications, 53(3), 519-532.

Norman, D. A. (2004). Emotional design: Why we love (or hate) everyday things. Basic Civitas Books.

Richardson, H. J. (2009). A 'smart house' is not a home: The domestication of ICTs. Information Systems Frontiers, 11(5), 599-608.

Ross, P. R., \& Wensveen, S. A. (2010). Designing aesthetics of behavior in interaction: Using aesthetic experience as a mechanism for design. International Journal of Design, 4(2), 3-13.

Submit Date: 12.01.2021, Acceptance Date: 01.02.2021, DOI NO: 10.7456/11102100/007

Research Article - This article was checked by iThenticate

Copyright (C) The Turkish Online Journal of Design, Art and Communication 
Saraiva, M., \& Ayanoğlu, H. (2019). Emotions and Emotions in Design. In Emotional Design in HumanRobot Interaction (pp. 57-70). Springer, Cham.

Saxbe, D., Graesch, A., \& Alvik, M. (2011). Television as a social or solo activity: Understanding families' everyday television viewing patterns. Communication Research Reports, 28(2), 180-189.

Schoenholz, M., \& Kolko, J. (2009). Designing in the face of change: the elusive push toward emotionally resonate experiences. New review of hypermedia and multimedia, 15(2), 211-220.

Song, S., Moustafa, H., \& Afifi, H. (2012). A survey on personalized TV and NGN services through contextawareness. ACM Computing Surveys (CSUR), 44(1), 1-18.

Strahilevitz, M., \& Myers, J. G. (1998). Donations to charity as purchase incentives: How well they work may depend on what you are trying to sell. Journal of consumer research, 24(4), 434-446.

Tsekleves, E., Cosmas, J., Aggoun, A., \& Loo, J. (2009). Converged digital TV services: The role of middleware and future directions of interactive television. International Journal of Digital Multimedia Broadcasting, 2009.

Tsekleves, E., Whitham, R., Kondo, K., \& Hill, A. (2011). Investigating media use and the television user experience in the home. Entertainment computing, 2(3), 151-161.

Veron, E. (1991). Analyses pour Centre d'Etudes des Telecommunications. Paris: Causa Rerum.

Warnke, P., \& Heimeriks, G. (2008). Technology foresight as innovation policy instrument: learning from science and technology studies. In Future-Oriented Technology Analysis (pp. 71-87). Springer, Berlin, Heidelberg.

\section{ELECTRONIC REFERENCES}

URL-1 University of California-San Diego. (2011, June 17). Coming to TV screens of the future: A sense of smell. ScienceDaily. Retrieved November 8, 2013 from

www.sciencedaily.com/releases/2011/06/110615094520.htm.

URL-2 Interaction Design Foundation, Hassenzahl, M. (2013). User experience and experience design. The encyclopedia of human-computer interaction, 2. Retrieved February 12, 2013 from https://www.interaction-design.org/literature/book/the-encyclopedia-of-human-computer-interaction-2nded/user-experience-and-experience-design 